\title{
Yochelcionella (Mollusca) from the late Middle Cambrian of Bornholm, Denmark
}

\author{
VIVIANNE BERG-MADSEN AND JOHN S. PEEL
}

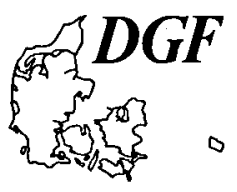

Berg-Madsen, V. \& Peel, J. S.: Yochelcionella (Mollusca) from the late Middle Cambrian of Bornholm, Denmark. Bull. geol. Soc. Denmark, Vol. 36, pp. 259-261. Copenhagen, December, 31st, 1987.

\begin{abstract}
The mollusc Yochelcionella is described from the Andrarum Limestone (late Middle Cambrian) of Ølea, Bornholm, representing the first record of this snorkel-bearing helcionellacean from Balto-Scandia. Its occurrence strengthens the similarity in terms of primitive molluscs between the Middle Cambrian of Bornholm and Australasia.
\end{abstract}

Vivianne Berg-Madsen, Geological Institute, Stockholm University, Box 6801, S-10691, Sweden. John S. Peel, Grønlands Geologiske Undersøgelse, Øster Voldgade 10, DK-1350 Copenhagen K, Denmark, December 3rd, 1986.

Yochelcionella Runnegar \& Pojeta 1974 is a small, cap-shaped mollusc characterised by the development of a tube-like extension of the subapical wall of the calcareous shell. The tube, termed a 'snorkel' by Runnegar \& Jell (1976, p. $115)$, was considered by the proposing authors to form the locus of the inhalant current to the mantle cavity (see also Pojeta \& Runnegar, 1976). In their restoration, the snorkel was located anteriorly above the head, and exhalant streams left the shell posteriorly (Fig. 1A). Geyer (in press), however, has suggested an alternative interpretation, supported by Peel \& Yochelson (in press), in which the snorkel is located posteriorly and the snorkel houses the exhalant stream from the mantle cavity (Fig. 1B). All these authors agree that Yochelcionella and other helcionellaceans were untorted molluses and not torted gastropods as suggested by Knight (1952) and Knight $e t$ al. (1960).

Yochelcionella was first described from the Middle Cambrian of Australia (Runnegar \& Pojeta, 1974; Runnegar \& Jell, 1976) but is now known from Lower-Upper Cambrian strata in many parts of the world (Missarzhevsky \& Mambetov, 1981; Peel, 1980; Pei, 1985; Runnegar \& Pojeta, 1980). It is described here for the first time from the Cambrian of Balto-Scandia, but its presence is not unexpected since other molluscan elements of the Middle Cambrian of Bornholm are known to occur together with Yochelcionella in strata of similar age in Australasia (Berg-Mad-

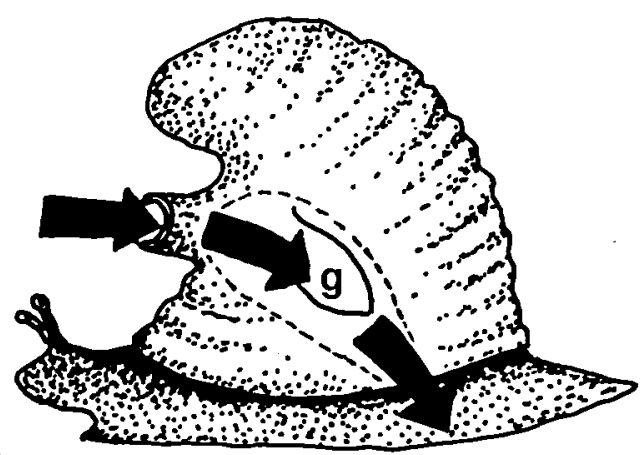

Fig. 1. Alternative reconstructions of water currents (arrowed) in Yochelcionella. A, the interpretation favoured by Pojeta \& Runnegar (1976) with the anteriorly located snorkel housing the inhalant stream. B, the reconstruction favoured by Geyer (in press) with the posteriorly located snorkel containing the exhalant current (g, gill). Modifjed after Pojeta \& Runnegar (1976, fig. 9). 

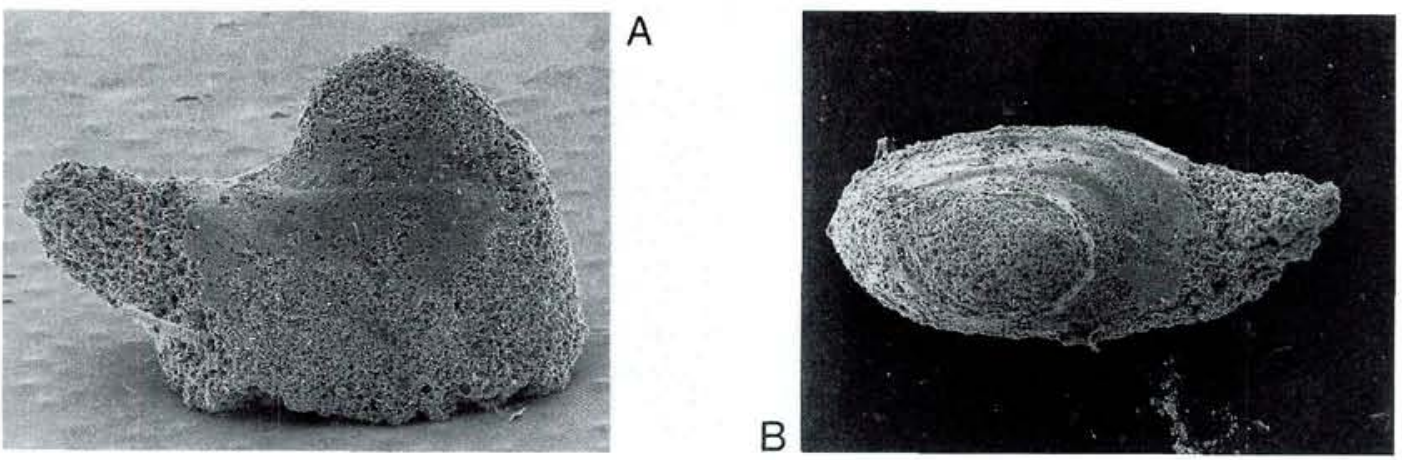

Fig. 2. Yochelcionella sp., MGUH 17.510, internal mould, Andrarum Limestone, late Middle Cambrian, Øleå, Bornholm. A, oblique lateral view showing the eroded snorkel (left), $\times 82 ; \mathrm{B}$, dorsal view, with snorkel to the right, $\times 76$.

sen, in press; Berg-Madsen \& Peel, 1978; Runnegar \& Jell, 1976).

\section{Genus Yochelcionella Runnegar \& Pojeta, 1974}

Type species. Yochelcionella cyrano Runnegar \& Pojeta, 1974, Coonigan Formation, New South Wales, Australia, early Middle Cambrian.

Discussion. Yochelcionella is distinguished from the related Eotebenna Runnegar \& Jell, 1976 by its tube-like snorkel. In the latter genus, the snor$\mathrm{kel}$ is connected to the apertural margin by a narrow slit. A such smaller, tube-like snorkel is present in Oelandia Westergård, 1936; this is located near the aperture and not high on the sub-apical wall, as in Yochelcionella (Peel \& Yochelson, in press).

\section{Yochelcionella $\mathrm{sp}$}

Fig. 2

Material. MGUH 17.510, the only known specimen.

Locality and age. Andrarum Limestone, Øleå, Bornholm, Solenopleura brachymetopa Zone, late Middle Cambrian. For further description see Berg-Madsen (1985b).

Description. A poorly preserved internal mould of the apical region of a species of Yochelcionella
Runnegar \& Pojeta, 1974 with the apertural margin not preserved. Apex worn, but apparently not overhanging. The concave sub-apical surface laterally compressed in dorsal view (Fig. 2B), with length (excluding snorkel) twice the width at the latest preserved growth stage. Lateral areas weakly rugose; a prominent shoulder occurs on the internal mould level with the upper margin of the snorkel (Fig. 2A). Snorkel circular in crosssection, its length not known. Thickness, structure and ornamentation of shell unknown.

Discussion. The specimen was figured without comment by Berg-Madsen (1985a). It is an internal mould of the apical (juvenile) portion of the shell, with its latest preserved growth stage occurring just adapertural of the snorkel. The poor preservation, combined with known ontogenetic variation in some species of Yochelcionella, e.g. Y. ostentata Runnegar \& Jell, 1976, does not permit specific assignment of the specimen from the Andrarum Limestone. Comparison with the well preserved silica replicas of the type material from Australia (Runnegar \& Jell, 1976) is difficult on account of the difference in preservation, although the apex appears to overhang the subapical surface in the latter material. However, phosphatic moulds from the Middle Cambrian Currant Bush Limestone tentatively assigned to the type species by Runnegar \& Jell (1976) show a similarly shaped apex to the Bornholm material.

An overhanging apex is not present in Yochelcionella ostentata Runnegar \& Jell, 1976, the earlier stages of which closely resemble the specimen from Øleå. The adult of the former species 
has a more circular apertural shape (Runnegar \& Jell, 1976, fig. 11, C1) but at the same growth stage as the Øleå specimen, the aperture is also approximately twice as long as wide.

Yochelcionella americana Runnegar \& Pojeta, 1980, from the Lower Cambrian of Pennsylvania (Runnegar \& Pojeta, 1980) and Newfoundland (J. S. Peel, unpublished information) is both more laterally compressed and more strongly coiled. Yochelcionella stylifera Missarzhevsky in Missarzhevsky \& Mambetov, 1981, from the Lower Cambrian of the Soviet Union is an erect form with strong comarginal rugations. Yochelcionella chinensis Pei, 1985, from the Lower Cambrian Xinji Formation of North China, closely resembles the specimen from Bornholm in its degree of lateral compression (Pei, 1985, plate 1 , fig. 1c). Rugae are prominent on the internal mould in the Chinese form, but a large collection of as similar form from the Lower Cambrian of Newfoundland indicates that this feature is very variable within the population (J. S. Peel, unpublished information).

Acknowledgements. J. S. Peel publishes with permission from the director, Grønlands Geologiske Undersøgelse.

\section{Dansk sammendrag}

Yochelcionella sp. (Mollusca) beskrives fra Andrarumkalken ved Øleå på Bornholm. Dette (eneste) eksemplar repræsenterer det hidtil første fund i Skandinavian. Ikke uventet forekommer det i en lagfølge indeholdende faunaelementer identiske med eller lig dem, som forekommer i Australiens Mellem Kambrium, hvorfra typematerialet er beskrevet.

\section{References}

Berg-Madsen, V. 1985a: Middle Cambrian biostratigraphy, fauna and facies in southern Baltoscandia. Acta Univ. Upsaliensis. Abstracts of Uppsala Dissertations from the Fac. of Sci. $781,37 \mathrm{pp}$.

Berg-Madsen, V. 1985b: A review of the Andrarum Limestone and the upper alum shale (Middle Cambrian) of Bornholm, Denmark. Bull. geol. Soc. Denmark 34, 133-143.

Berg-Madsen, V. in press: Tuarangia from Bornholm, Denmark and similarities in Baltoscandian-Australasian late Middle Cambrian faunas. Alcheringa.

Berg-Madsen, V. \& Peel, J. S. 1978: Middle Cambrian monoplacophorans from Bornholm and Australia, and the systematic position of the bellerophontiform molluscs. Lethaia $11,113-125$.

Geyer, G. in press: Mittelkambrische Mollusken aus Marokko und Spanien. Senckenberg. leth. 67.

Knight, J. B. 1952: Primitive fossil gastropods and their bearing on gastropod classification. Smithson. Misc. Collns. $117: 13,56 \mathrm{pp}$.

Knight, J. B., Cox, L. R., Keen, A. M., Batten, R. L., Yochelson, E. L., Ludbrook, N. H., Robertson, R., Yonge, C. M. \& Moore, R. C. 1960: Systematic descriptions Archaeogastropoda), Supplement (Paleozoic and some Mesozoic Caenogastropoda and Opisthobranchia). In Moore, R. C. (ed.): Treatise on Invertebrate Paleontology I, Mollusca, I169-1332. Geol. Soc. Am. and Univ. of Kansas Press.

Missarzhevsky, V. V., \& Mambetov, A. M. 1981: Stratigraphy and fauna of the Cambrian and Precambrian boundary beds of Maly Karatau. Trudy Akad. Nauk SSSR 326, 90 pp. (In Russian with English summary).

Peel, J. S. 1980: Yochelcionellids from the Early and Late Cambrian of North Greenland. Rapp. Grønlands Geol. Unders. 102, p. 44 (only).

Peel, J. S. \& Yochelson, E. L. in press: New information on Oelandia (Mollusca) from the Middle Cambrian of Sweden. Bull. geol. Soc. Denmark.

Pei Fang 1985: First discovery of Yochelcionella from the Lower Cambrian of China and its significance. Acta Micropalaeontol. Sinica. 2:4, 395-400.

Pojeta, J., Jr. \& Runnegar, B. 1976: The paleontology of rostroconch molluses and the early history of the phylum Mollusca. Prof. Pap. U.S. Geol. Surv. 968, 88 pp.

Runnegar, B. \& Jell, P. A. 1976: Australian Middle Cambrian molluscs and their bearing on early molluscan evolution. Alcheringa 1, 109-138.

Runnegar, B. \& Pojeta, J. 1974: Molluscan phylogeny: the paleontological viewpoint. Science 186, 311-317.

Runnegar, B., \& Pojeta, J., Jr. 1980: The monoplacophoran mollusc Yochelcionella identified from the Lower Cambrian of Pennsylvania. J. Paleont. 54, 335-336. 